\title{
Proposal for new method to evaluate lichen refuges
}

\author{
Wojciech Gruszka ${ }^{1}$, Ludwik Lipnicki² \\ ${ }^{1}$ Department of Biological Sciences, Faculty of Physical Culture in Gorzów Wlkp., Poznan University of Physical \\ Education, Estkowskiego Str. 13, 66-400 Gorzów Wlkp., Poland \\ *corresponding author e-mail: elm1@interia.pl \\ ${ }^{2}$ Department of Tourism and Health Sciences, The Jacob of Paradies University, \\ Teatralna Str. 25, 66-400 Gorzów Wlkp., Poland
}

Received: 27 March 2019 / Accepted: 17 April 2020

\begin{abstract}
The paper presents a novel proposal for the evaluation of lichen refuges based on observations conducted in mesoregions Krajeńskie Lakeland, Tucholskie Forest and Charzykowska Plain in the last 20 years. Four basic parameters should be taken into account when evaluating the natural significance of refuges. These are: the stability of the area, biodiversity (species abundance), the number of sites where valuable species occur and the possibility of their dispersal. The characteristics and point scales of these parameters, as well as examples of calculations, are presented.
\end{abstract}

Keywords: lichens, refuges, endangered species, ecosystem fragmentation.

\section{Introduction}

According to Collins English Dictionary (2014), a refuge is a geographical region which has not been changed and now constitutes a safe haven for relict fauna and flora. Many researchers (e.g. Szweykowscy A. \& J, 1993; Falińska, 1997; Dyduch-Falniowska et al., 1999; Symonides, 2007) consider the presence of valuable species as the sole (or the most important) distinguishing feature of refuge.

This definition also applies to refuges of lichens where they form a cluster of valuable species. For example, Cieśliński et al. (1996), Czyżewska and Cieśliński (2003), Kubiak (2013), Matwiejuk (2015) and Perhans et al. (2009) consider forest complexes rich in lichen species to be refuges. Similarly, Kościelniak $(2004,2008)$ reports that the primary and natural forests of the Bieszczady Mountains serve as refuges and Kapek (2014) - in the same region regards abandoned villages as refuges. Many authors (e.g. Cieśliński, 2000, 2006; Kossowska, 2002) emphasize the role of protected objects in preserving valuable lichen species. Only a few studies consider the issue of refuges at the same time as the analysis of habitat condition and change, e.g. in British Columbia (Doering \& Coxon, 2010) or in Australia (Kantvilas, 2018). Berryman and McCune (2006), in a study based in the western part of Oregon State, evaluate the possibility of preserving valuable epiphytic lichen species depending on the age of trees. A few researchers, e.g. Himelbrant et al. (2018), also take into account the historical aspect of changes in the lichen biota when considering the role of lichen assemblies in the analysed area (in the Leningrad Region, Russia).

The aim of this paper is to point out that when designating a site as a refuge for lichens, it is not only the presence of endangered, rare or protected relict species, etc., that should be taken into account. It is also very important to determine the chances of their persistence and dispersion within the site boundaries. Moreover, the value of sites as refuges, even if they are rich in quantity and quality in terms of valuable taxa, cannot always be compared; they may differ in terms of habitat condition (mainly 
the presence and diversity of the substrate available for settlement), local microclimatic features, isolation from the source of dispersal, etc. These difficulties in assessing and comparing the natural value of sites, even within the same region, were pointed out by Cieśliński (2009).

The possibilities for determining and designating lichen refuges differently than has been performed heretofor were initially signalled in a publications by Gruszka (2017) and Gruszka and Lipnicki (2019). The proposal presented here is much more complete and should become the subject of substantive discussion.

\section{Study area}

The study covered the eastern part of the South Pomeranian Lakeland macroregion in the central part of northern Poland, comprising three adjacent mesoregions: Krajeńskie Lakeland (area $4380 \mathrm{~km}^{2}$ ), Tuchola Forest (area $2400 \mathrm{~km}^{2}$ ) and Charzykowska Plain (area $2100 \mathrm{~km}^{2}$ ) (Kondracki, 2001) (Fig. 1).

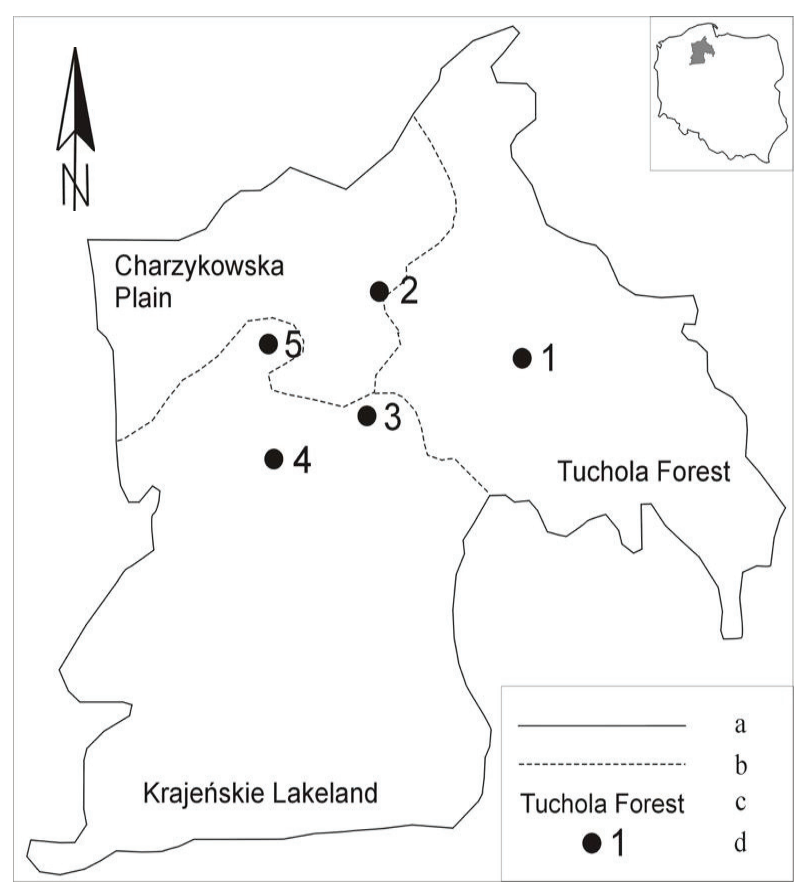

Figure 1. Study area; $a$ - boundaries of the study area, $b$ - boundaries of mesoregions, $\mathrm{c}$ - names of mesoregions, $\mathrm{d}$ - refuges described: 1 - Kręgi Kamienne Reserve, 2 - Bór Chrobotkowy Nature Reserve, 3 - Nature monument roadside alley, 4 - Sosny Nature Reserve, 5 - Osiedle Kormoranów Nature Reserve

Krajeńskie Lakeland is mainly agricultural (more than $70 \%$ of the area) but forest (the vast majority very ho- mogeneous) cover is $27.3 \%$ (Waldon \& Ratyńska, 2008; Trampler et al., 1990). The dominant forest associations are pine and mixed forest, although there are also large associations of mixed deciduous forests (Umiński, 1991). Mesoregions Tucholskie Forest and Charzykowska Plain are located in a vast sandur and on a large area occupied by one of the largest forest complexes in the lowland part of Poland - Bory Tucholskie. These are almost entirely pine forests and only small areas, mainly in river valleys, are occupied by deciduous or mixed forests.

Examples using the described method are presented on the basis of analysis of the following areas, which function as lichen refuges in the research locality.

\section{Kręgi Kamienne Reserve}

This reserve, with an area of 16.91 ha, was established in 1958 in order to protect 12 stone circles (about 300 stones) and approximately 30 burial mounds. In the order of 90 species of lichen grow on the boulders' surfaces, forming one of the largest concentrations of mountain species in the Polish Lowland; in many cases these are postglacial relics. This represents the only concentration of valuable rock lichens in the study area.

\section{Bór Chrobotkowy Nature Reserve}

This is a forest reserve with an area of 41.5 ha. In relation to the whole study area (Fig. 1), the area is distinguished by containing the full species composition of terrestrial lichens, characteristic of Cladonio-Pinetum. There are also species of ground lichens, which are very rare in the country and region, including Cladonia stellaris, Stereocaulon taeniarum and Flavocetraria nivalis, and which can only be found in two lowland sites in Poland.

\section{Nature monument - roadside alley}

The alley is about $1.5 \mathrm{~km}$ long, stretching along both sides of the road between Powałki and Jarcewo. Very rare taxa grow on the trunks of trees here, known from only a few sites in the whole analysed area (including Parmelina tiliacea and Anaptychia ciliaris), as well as other protected and endangered species (e.g. Bryoria sp. div., Ramalina sp. div.).

\section{Sosny Nature Reserve}

This reserve was established in 1984 and covers an area of 1.49 ha. A fragment of Pomeranian fertile beech forest Galio odorati-Fagetum and numerous monumental pine trees are protected.

\section{Osiedle Kormoranów Nature Reserve}

This reserve was established in 1956. Under protection are the biocenosis of Pomeranian fertile beech forest $\mathrm{Ga}$ lio odorati-Fagetum, monumental specimens of beech and the landscape of the edge of moraine upland. The reserve 
contains a number of rare and endangered lichen species (Gruszka, 2010; Gruszka \& Janczar, 2010).

\section{Methods}

Studies that involve designating areas as refuges require careful examination of the terrain of reference, in order to distinguish those especially valuable species that are indicators of the refuge.

The main field study in the Krajeńskie Lakeland mesoregion was conducted in 2009-2014 for a doctoral dissertation (Gruszka, 2014) and this was continued up to 2017 (Gruszka 2017; Gruszka \& Lipnicki, 2019).

Lichenological studies covering the whole forest complex of Bory Tucholskie were mainly conducted during the last quarter of the 20th century (i.e. Lipnicki, 1990). They enabled habitat fragments which form refuges for lichens to be identified. The results of these studies were used in the project documentation for a national park, landscape parks and numerous nature reserves (Lipnicki, 1992, 2006, 2012).

The presented attempt to evaluate selected refuges was conducted on the basis of their comprehensive evaluation in terms of analysed parameters. The following factors were taken into account: species diversity of lichens, the number of the most valuable species and their habitat requirements, size of the area, natural characteristics, immediate surroundings, anthropopressure and other threats. The nature, direction and pace of changes in the lichen biota were also evaluated in the refuges with the longest history of research (Kręgi Kamiennie Reserve, Bór Chrobotkowy).

The final evaluation of the quality of refuges was determined on the basis of a five-stage scale (Table 1) after summing up the points assigned to each parameter.

Table 1 . Lichen refuge quality scale

\begin{tabular}{|c|c|}
\hline Total sum of points & Value of refuge \\
\hline 4 & negligible \\
\hline $5-8$ & small \\
\hline $9-12$ & moderate \\
\hline $13-16$ & large \\
\hline $16-20$ & very large \\
\hline
\end{tabular}

In order to evaluate lichen refuges, it is proposed that four parameters are analysed. These are: abundance, prevalence and - most strongly related - perspective and permanence. Below is a justification for their inclusion, descriptive characteristics and the criteria for estimating values.

\subsection{Abundance}

The expressed percentage of a given species refuge among all those distinguished as the most valuable in the region.

This parameter can only be determined after collecting data from the whole (larger) area and indicating valuable species. It is necessary to determine to which refuge area it refers (e.g. mesoregion, city, part of the country) and to characterize the local biodiversity as precisely as possible. In this way, a "reference point" will be defined (background), i.e. a model for analysing the local diversity of the lichen biota (Table 2).

Table 2. Lichen abundance levels

\begin{tabular}{|c|c|c|}
\hline $\begin{array}{c}\text { Lichen } \\
\text { abundance }\end{array}$ & Quality characteristics of refuges & $\begin{array}{l}\text { Num- } \\
\text { ber of } \\
\text { points }\end{array}$ \\
\hline negligible & $\begin{array}{l}\text { A small number of regionally } \\
\text { valuable species }(<10 \%) \text {; local } \\
\text { taxa are clearly dominant }\end{array}$ & 1 \\
\hline small & $\begin{array}{l}\text { A still small number but clearly } \\
\text { visible addition of regionally } \\
\text { valuable species }(10-20 \%) \text { to the } \\
\text { overall biota of lichens }\end{array}$ & 2 \\
\hline average & $\begin{array}{l}\text { Number of regionally valuable } \\
\text { species is slightly higher }(21-30 \%) \\
\text { than in other parts of the analysed } \\
\text { area; however, locally frequent } \\
\text { and widespread species still } \\
\text { predominate }\end{array}$ & 3 \\
\hline large & $\begin{array}{l}\text { Clearly distinguishable share of } \\
\text { valuable taxa, with a significant } \\
\text { or number of regionally valuable } \\
\text { species (31-40\%), much larger } \\
\text { than in other parts of the analysed } \\
\text { area, rare and common taxa coexist }\end{array}$ & 4 \\
\hline exceptional & $\begin{array}{l}\text { High or very high number of } \\
\text { regionally valuable species } \\
(>40 \%) \text {, undoubtedly } \\
\text { a distinguishing area on the scale } \\
\text { of analysed area }\end{array}$ & 5 \\
\hline
\end{tabular}

\subsection{Prevalence}

The percentage expressed represents the proportion of sites where the valuable species occurs in relation to all sites studied in a particular refuge area.

Prevalence is a quantitative parameter that determines the abundance of a population of valuable species or a group of such taxa in the refuge. In the case of a large number of valuable species it is possible to select a taxon that is representative and (according to the researcher) the 
most valuable for a given region. To indicate the numerical value of the prevalence parameter, a modified frequency scale, after Czachorowski (2004), was adopted (Table 3).

Table 3. Prevalence levels of valuable species

\begin{tabular}{|c|c|c|}
\hline Prevalence (\%) & Descriptive frequency & $\begin{array}{c}\text { Number } \\
\text { of points }\end{array}$ \\
\hline$<5$ & very rare & 1 \\
\hline $5-19,9$ & rare & 2 \\
\hline $20-49,9$ & frequent & 3 \\
\hline $50-79,9$ & pervasive & 4 \\
\hline $80 \% \geq$ & common & 5 \\
\hline
\end{tabular}

\subsection{Perspective}

Determines the extent to which the number of sites of valuable species in the refuge area can be preserved (or increased) in the future.

The perspective parameter is determined by analysing the long-term viability of a species existence and its spread (Table 4). The species' biology and habitat requirements should be taken into account; a lack of such knowledge may result in an incorrect classification of the area. If the site has been previously subject to an inventory study, historical data may be useful in analysing this parameter. This parameter allows trends in population change to be deduced.

Table 4. Refuge perspective scale

\begin{tabular}{|l|l|c|}
\hline \multicolumn{1}{|c|}{$\begin{array}{c}\text { Refuge } \\
\text { perspective }\end{array}$} & \multicolumn{1}{|c|}{ Descriptive characteristics } & $\begin{array}{c}\text { Number } \\
\text { of } \\
\text { points }\end{array}$ \\
\hline critical & $\begin{array}{l}\text { Lack of possibility of taxa spread, } \\
\text { high risk to population sustainability }\end{array}$ & 1 \\
\hline stagnant & $\begin{array}{l}\text { Minor or very limited spread } \\
\text { potential; population sustainability } \\
\text { may be at risk }\end{array}$ & 2 \\
\hline average & $\begin{array}{l}\text { Slight but visible potential for } \\
\text { spreading and increasing the number } \\
\text { of sites; there is no clear threat to } \\
\text { the sustainability of the population }\end{array}$ & 3 \\
\hline substantial & $\begin{array}{l}\text { High potential for spreading and } \\
\text { increasing the number of sites; } \\
\text { undisturbed population }\end{array}$ & 4 \\
\hline colonization & $\begin{array}{l}\text { Extremely large and supportive } \\
\text { opportunities to spread and increase } \\
\text { the number of sites }\end{array}$ & 5 \\
\hline
\end{tabular}

\subsection{Permanence}

Determines the long-term ability of the area to preserve the refuge function and the existence of valuable species within its boundaries.

The permanence parameter should be analysed in terms of the resilience of the entire area in the face of adverse external factors. It is important to assess whether the area has stable system features or is temporary with low homeostatic capacity. Stability is a complex parameter; its acceptance and the determination of its extent depend on the observer's experience in predicting long-term possible changes in the area. The final assessment presented in Table 5 may be based on an analysis of one species or a group of taxa.

Table 5. Refuge resilience scale

\begin{tabular}{|c|c|c|}
\hline Permanence & Descriptive characteristics & $\begin{array}{l}\text { Number } \\
\text { of points }\end{array}$ \\
\hline ephemeral & $\begin{array}{l}\text { An area with minimal self- } \\
\text { regulation. Completely susceptible } \\
\text { to disturbing factors. Refuge fading } \\
\text { or degrading. Lack of possibility } \\
\text { to preserve the species within } \\
\text { a foreseeable time frame }\end{array}$ & 1 \\
\hline threatened & $\begin{array}{l}\text { An area with low self-regulation. } \\
\text { Partially resistant to moderate } \\
\text { disturbance; low buffering } \\
\text { properties. Low preservation } \\
\text { potential for species, high likelihood } \\
\text { of extinction }\end{array}$ & 2 \\
\hline $\begin{array}{l}\text { relatively } \\
\text { stable }\end{array}$ & $\begin{array}{l}\text { An area with significant self- } \\
\text { regulation. Completely resistant to } \\
\text { moderate disturbance; buffering } \\
\text { capacity ensures habitat stability. } \\
\text { Average preservation potential for } \\
\text { species, but low extinction potential }\end{array}$ & 3 \\
\hline secure & $\begin{array}{l}\text { An area with full self-regulatory } \\
\text { capacity. Resistant to higher } \\
\text { disturbance factors; low risk of } \\
\text { changes in habitat conditions. Very } \\
\text { high preservation potential for } \\
\text { species and no threat of extinction }\end{array}$ & 4 \\
\hline supportive & $\begin{array}{l}\text { Lack of disturbance factors or } \\
\text { buffering capacity of the site } \\
\text { ensures full habitat permanence and } \\
\text { promotes the spread of taxa }\end{array}$ & 5 \\
\hline
\end{tabular}




\section{Examples applying the methodology}

\subsection{Kręgi Kamienne Reserve}

a) Abundance: most taxa are regionally extremely valuable and rare, 5 points

b) Prevalence: most of the valuable species are common (90\% of sites) within the larger area, 5 points

c) Perspective: colonization present (evidenced by the settlement of lichens on boulders exposed as a result of archaeological work in the last several decades), 5 points

d) Permanence: supportive, 5 points.

Sum of points: 20; value of refuge: very large; notes: outstanding refuge with sustainable resources; it requires that the behaviour of tourists be supervised.

\subsection{Bór Chrobotkowy Nature Reserve}

a) Abundance: regionally exceptional, 5 points

b) Prevalence: calculation of this parameter was based on analysis of the four most valuable elements of the site: the general set of species typical for Cladonio-Pinetum habitat and the populations of Cladonia stellaris, Flavocetraria nivalis and Stereocaulon taeniarum (Table 6).

c) Perspective and permanence: the evaluation of perspective and permanence considered the same elements of the site as in the prevalence evaluation (Table 7).

Sum of points: 16; value of refuge: large; notes: requires active protection to slow down processes of natural succession.

Table 6. Assessment of lichen refuges: values of the prevalence parameter for the most valuable elements of the Bór Chrobotkowy Reserve

\begin{tabular}{|l|c|c|c|}
\hline \multirow{2}{*}{ Analysed element } & \multicolumn{3}{|c|}{ Evaluation } \\
\cline { 2 - 4 } & Percentage & Descriptive & Score \\
\hline $\begin{array}{l}\text { Set of species typical } \\
\text { for Cladonio-Pinetum }\end{array}$ & $95 \%$ & common & 5 \\
\hline Cladonia stellaris & $85 \%$ & common & 5 \\
\hline Flavocetraria nivalis & $15 \%$ & rare & 2 \\
\hline Stereocaulon taeniarum & $12 \%$ & rare & 2 \\
\hline Total & $\cong 52 \%$ & pervasive & 4 \\
\hline
\end{tabular}

Table 7. Assessment of lichen refuges: results of the analysis of perspective and permanence parameters for the Bór Chrobotkowy Reserve

\begin{tabular}{|l|c|c|c|c|}
\hline & \multicolumn{2}{|c|}{ Perspective } & \multicolumn{2}{c|}{ Permanence } \\
\hline Analysed element & $\begin{array}{c}\text { Descriptive } \\
\text { evaluation }\end{array}$ & Score & $\begin{array}{c}\text { Descriptive } \\
\text { evaluation }\end{array}$ & Score \\
\hline $\begin{array}{l}\text { Set of species typical } \\
\text { for Cladonio-Pinetum }\end{array}$ & substantial & 4 & supportive & 5 \\
\hline Cladonia stellaris & colonization & 5 & supportive & 5 \\
\hline Flavocetraria nivalis & stagnant & 2 & $\begin{array}{c}\text { relatively } \\
\text { stable }\end{array}$ & 3 \\
\hline $\begin{array}{l}\text { Stereocaulon } \\
\text { taeniarum }\end{array}$ & stagnant & 2 & $\begin{array}{c}\text { relatively } \\
\text { stable }\end{array}$ & 3 \\
\hline Total & average & $<3$ & secure & 4 \\
\hline
\end{tabular}

\subsection{Nature monument - roadside alley between Powałki and Jarcewo}

a) Abundance: most taxa are regionally valuable 5 points

b) Prevalence: based on Parmelina tiliacea as a representative species $-30 \%, 3$ points

c) Perspective: stable populations colonizing other trees only at a low and uneven rate (based on multiannual observations) - average, 3 points

d) Permanence: the population of target species and other valuable taxa are not at risk unless local conditions change (ageing and removal of trees, increased motor vehicle traffic) - relatively stable, 3 points.

Sum of points: 14; value of refuge: large; notes: requires supervision in order to prevent increased motor vehicle traffic

\subsection{Sosny Nature Reserve}

a) Abundance: 11 taxa of 43 are regionally valuable (25\%), 3 points

b) Prevalence: valuable species identified at individual sites, 1 point

c) Perspective: very few potential sites, $\mathbf{2}$ points

d) Permanence: this reserve experiences intensive shrub growth, high probability of extinction of lichens due to changes in habitat conditions, 2 points.

Sum of points: 8 ; value of refuge: small; notes: surveillance zone as a result of natural succession.

\subsection{Osiedle Kormoranów Nature Reserve}

a) Abundance: 13 taxa of 43 regionally valuable (30\%), 3 points

b) Prevalence: based on Ramalina balica as a representative species, 1 point 
c) Perspective: many potential places to be occupied by the species, 4 points

d) Permanence: lack of major disturbance factors, the ecosystem of this area retains high buffering potential, 5 points.

Sum of points: 13; value of refuge: large; notes: this area with population of valuable species requires constant monitoring.

\section{Discussion}

Refuges have an increasing role in preserving and maintaining biodiversity, particularly in a landscape modified by people. The identification and protection of such areas can increase the chances of survival of the most valuable species in the region. In the process of broadly-understood anthropogenic transformations and long-standing demands for the protection of lichens (e.g. Motyka, 1934; Szwejkowski \& Tobolewski, 1959; Lipnicki, 1988, 1991) refuges have, and will have, an increasingly important role in the preservation of biodiversity (Cieśliński \& Czyżewska, 2002).

The authors of this paper, based on many years of field research and activities for the protection of valuable and endangered lichen sites, present four basic parameters for the evaluation of refuges. These parameters are: abundance, prevalence, perspective and permanence. They are sufficient to evaluate the value of potential lichen refuges.

In the case of abundance, the designation of a refuge area is due to the fact that the regional distribution of taxa is an unstable feature. The same species can be assigned to different categories of threats - cf. Regional Red Lists (e.g. Czyżewska, 2003). However, the Red List itself defines only the risk of extinction of species, while other aspects (e.g. phylogenetic, historical, cultural) may jointly significantly recommend a particular species for protection (Kędra, 2013). The parameter patronize large-area refuges due to the presence of more valuable species within their borders - (often even as single site). At the same time, it may underestimate the values of those within which valuable but few (or even single) species were found. The percentage ranges assigned to each degree (although quite wide) may turn out to be too rigid and perhaps descriptive characteristics should be introduced to allow more freedom in choosing the grade.

The need to calculate the prevalence level results from the fact that each species has its own population threshold (sites, number of individuals in the site, etc.), below which the population is threatened with extinction from year to year (Wilson, 1999). According to Markowski and Skrok (1999), the probability of population disappearance of a small number of sites in the remaining parts of a larger area is much higher than the probability of increasing their numbers. Even a common species, but for which a significant reduction in the number (or deterioration state) of habitats has been identified, may be considered to be at high risk of extinction (Kędra, 2013). From the authors' observations, the parameter quite well describes the prevalence in the refugium of a given species (or species). However, these observations focused on relatively small areas with clearly defined positions. The problem with its determination may appear in larger areas - which will require counting all surveyed stands during field work.

Perspective expresses the potential for the dispersion of valuable species Lichens are characterized by a limited range of spreading through diasporas. These distances usually do not exceed 100 m (i.e. Öckinger et al., 2005; Scheidegger \& Werth, 2009; Jüriado et. al., 2011). According to, e.g., Selva (1994), Gu et al. (2001) and Kubiak (2013), the possibility of overcoming environmental barriers and the occupation of new habitats by many taxa is decreasing as a result of, among other factors, the dispersion of their sites. As a result, migration and opportunities for re-colonization are limited or even non-existent, and the risk of their extinction in a given area increases. This is because we are dealing with very small populations which tend to lose genetic diversity and, therefore, the ability to adapt to a changing environment (Pullin, 2004). Occupation of a larger area of the ecosystem means more stable conditions, favourable to colonization of the habitat, and thus potentially more and larger populations (Wilson, 1999). The parameter is very difficult to determine. We try to estimate the theoretical situations that may (but do not have to) occur in the future. This determination enables the development of practical actions that will lead to an increase in lichen sites and thus increasing the quality of the refuge.

While the previous parameter (perspective) was analysed from the point of view of the species, permanence considers the area as a whole. Changes in habitat conditions may initiate processes of dynamic change in the composition and structure of the ecosystem. In the case of lichens (especially those with a very narrow range of ecological requirements) such changes are particularly dangerous. This is mainly due to their slow growth rate, high sensitivity to anthropogenic factors and specific habitat selectivity. Regeneration of their population (despite the richness of potential sites) in changed conditions is difficult or even impossible. Factors which have a negative impact on lichens have a complex effect and, in many cases, it is difficult to identify the one responsible for the impoverishment of the lichen biota (Fałtynowicz, 2003). One of the threats to species is, e.g., a reduction in the area where potentially favourable conditions for the growth of of lichens has existed thus far. The supportive properties of natural ecological systems, characterized by stable ecosystems, e.g. forest ecosystems, weaken with their fragmentation (Cieśliński et al., 1996). In the case of areas subject to 
strong anthropogenic pressure, the possibility and probability of the effectiveness of limiting the negative effects of these processes should be considered (active protection). In the authors' opinion, this is the most important parameter. All areas presented in the publication are protected by law, and that's why permanence parameters reached (usually) high values. But negative (from the point of view of lichen ecology) are also natural processes (plants succession, extinction of stands). That mostly was lowers the values (not anthropogenic factors).

\section{Conclusions}

The methodology presented above for the evaluation of the quality of lichen refuges may seem simplistic, but it is relatively quick and does not require support from statistical analysis. However, the method requires a very good knowledge of the research area, and the results must be well-argued. Therefore, the methodology is directed at more experienced lichenologists. The evaluation method presented may be helpful (and in some cases even crucial) in the identification of risk to the stability and continuity of refuges and subsequent development of their protection. Since the problem of refuges is largely unaddressed in the lichenological literature, it seems advisable to continue researching this problem in other areas. Using this method to check the quality of refugia for other groups of organisms (for example bryophytes or vascular plants) seems to be possible but requires verification.

\section{References}

Berryman S. \& McCune B., 2006, Epiphytic lichens along gradients in topography and stand structure in western Oregon, USA. North American Fungi 1(1): 1-38. doi:http://dx.doi.org/10.2509/pnwf.2006.001.002

Cieśliński S., 2000, Białe Ługi Reserve: a refuge of the forest lichen flora of the Góry Świętokrzyskie Mountains. Fragmenta Floristica et Geobotanica 45(1-2): 485-492.

Cieśliński S., 2006, The Krzemionki Opatowskie Reserve: a refuge of lichen in Central Poland. Nature Conservation 62: 13-25.

Cieśliński S., 2009, Znaczenie ochrony rezerwatowej dla zachowania bioty porostów (Ascomycota lichenisati) w Puszczy Kozienickiej [The role of nature reserves in conservation of the lichen biota (Ascomycota Lichenisati) in Kozienicka Primeval Forest]. Parki Narodowe i Rezerwaty Przyrody 28(1): 3-35.

Cieśliński S. \& Czyżewska K., 2002, Porosty Puszczy Białowieskiej na tle innych kompleksów leśnych w Polsce Północno-Wschodniej [Lichens of Białowieża primeval forest in comparison with other forest com- plexes in north-eastern Poland]. Kosmos 51(4): 443451.

Cieśliński S., Czyżewska K., Faliński J.B., Klama H., Mułenko W. \& Żarnowiec J., 1996, Relikty lasu puszczańskiego. Zjawiska reliktowe [Relicts of the primeval (virgin) forest: relict phenomena], [in:] J.B. Faliński (ed.), Białowieski Park Narodowy (19211996) w badaniach geobotanicznych [Białowieża National Park in geobotanical research]. Phytocoenosis 4: 47-64.

Collins English Dictionary, 2014, version online at www. collinsdictionary.com/dictionary/english/refugium [Accessed: 14.10.2019)].

Czachorowski S., 2004. Opisywanie biocenozy - zoocenologia, skrypt elektroniczny dla magistrantów [Descriptioning of biocoenose - zoocoenology, course book for graduate students], Mscr. www.uwm.edu.pl/czachor/ publik/pdf-inne/zoocenozy.pdf

Czyżewska K., (ed.), 2003. Zagrożenie porostów w Polsce [Threat to lichens in Poland]. Monographiae Botanicae 91.

Czyżewska K. \& Cieśliński S., 2003, Porosty - wskaźniki niżowych lasów puszczańskich w Polsce [Lichens - indicators of lowland old-growth forests in Poland], [in:] K. Czyżewska (ed.), Zagrożenie porostów w Polsce [Threat to lichens in Poland]. Monographiae Botanicae 91: 223-239.

Doering M. \& Coxson D., 2010, Riparian alder ecosystems as epiphytic lichen refugia in sub-boreal spruce forests of British Columbia. Botany 88(2): 144-157. doi:10.1139/B09-096

Dyduch-Falniowska A., Kaźmierczakowa R., MakomaskaJuchiewicz M., Perzanowska-Sucharska J. \& Zając K., 1999, Ostoje przyrody w Polsce [Natural sites in Poland]. Instytut Ochrony Przyrody PAN, Kraków.

Falińska K., 1997, Ekologia roślin [Plant Ecology]. Wydawnictwo Naukowe PWN, Warszawa.

Fałtynowicz W., 2003, Różnorodność gatunkowa - porosty [in:] R. Andrzejewski, A. Weigle (eds.), Różnorodność biologiczna Polski [Biological diversity of Poland]. Narodowa Fundacja Ochrony Środowiska, Warszawa: 29-35.

Gruszka W., 2010, Porosty rezerwatu „Osiedle Kormoranów” na Pojezierzu Krajeńskim (północno-zachodnia Polska) [Lichens of the "Osiedle Kormoranów" reserve in Krajeńskie Lake District (north-western Poland)]. Parki Narodowe i Rezerwaty Przyrody 29(2): 41-49.

Gruszka W., 2014, Refugia porostów epifitycznych na Pojezierzu Krajeńskim [Epiphytic lichens refuge in the Krajeńskie Lakeland]. Ph.D. dissertation, Nicolaus Copernicus University, Torun.

Gruszka W., 2017, The concept of lichen refugia classification. A proposal based on the case study of Krajeńskie Lakeland, Poland. Ecological Questions 27(3): 65-75. 
Gruszka W. \& Lipnicki L., 2019, Standard procedure for the identification of lichen refuges: a case study of the Krajeńskie Lakeland area in Poland. Ecological Questions, 30(4): 19-27.

Gruszka W. \& Janczar R., 2010, Nowe stanowiska Ramalina baltica Lettau (zlichenizowane ascomycota) w północno-zachodniej Polsce [New localities of Ramalina baltica (lichenized Ascomycota) in north-western Poland]. Badania Fizjograficzne Seria B Botanika 1(59): 185-189.

Gu W.-D., Kuusinen M., Konttinen T. \& Hanski I., 2001, Spatial pattern in the occurrence of the lichen Lobaria pulmonaria to new localities and a review of the transplanting of lichens. Windhalia 18: 57-64.

Himelbrant D., Stepanchikova I., Kuznetsova E., Motiejūnaitė J. \& Konoreva L., 2018, Konevets Island (Leningrad Region, Russia) - a historical refuge of lichen diversity in Lake Ladoga. Folia Cryptogamica Estonica 55: 51-78. https://doi.org/10.12697/ fce.2018.55.07

Jüriado I., Liira J., Csencsics D., Widmer I, Adolf C., Kohv K. \& Scheidegger C., 2011, Dispersal ecology of the endangered woodland lichen Lobaria pulmonaria in managed hemiboreal forest landscape. Biodiversity Conservation 20(8): 1803-1819.

Kantvilas G., 2018. South Australian lichens - A Kangaroo Island case study. Swainsona 30: 17-24.

Kapek N., 2014, Opuszczone wsie w Bieszczadach jako ostoje zagrożonych i chronionych gatunków porostów w Polsce [Vanished villages in the Bieszczady Mts as refuges of threatened and protected lichens in Poland]. Fragmenta Floristica et Geobotanica Polonica 21(1): 147-164.

Kędra K., 2013, Miary rzadkości i zagrożenia gatunków zależność od skali, na przykładach gatunków grzybów [Scale-sensitive measures of rarity and extinction risk: a case study of fungal species]. Przegląd Przyrodniczy 24(3): 27-44.

Kondracki J., 2001, Geografia regionalna Polski [The Regional Geography of Poland]. Państwowe Wydawnictwo Naukowe, Warszawa.

Kościelniak R., 2004, Porosty (Lichenes) Bieszczadów Niskich [The Lichens of the Bieszczady Niskie Mts]. Fragmenta Floristica et Geobotanica Polonica Supplementum 5: 3-164.

Kościelniak R., 2008, Znaczenie lasów o charakterze pierwotnym i naturalnym dla zachowania różnorodności gatunkowej porostów w Bieszczadach [The importance of primeval and natural forests for preservation of species diversity of lichens in the Bieszczady Mts]. Roczniki Bieszczadzkie 16: 67-76.

Kossowska M., 2002, Ostoja rzadkich porostów epifitycznych na jodłach w Wąwozie Szklarki (Karkonoski Park Narodowy) [Refuge of rare epiphytic lichens on firs in Szklarka Gully (Karkonosze National Park)]. Przyroda Sudetów Zachodnich [Nature of the Western Sudetes] 5: 85-92.

Kubiak D., 2013, Znaczenie starodrzewu dla zachowania różnorodności porostów w lasach na przykładzie pozostałości Puszczy Mazowieckiej [The significance of old-growth forests in maintaining lichen diversity an example from the remnants of the Mazovian Forest]. Leśne Prace Badawcze 74(3): 245-255.

Lipnicki L., 1988, Wymagające ochrony stanowiska porostów na terenie Borów Tucholskich [High conservation value sites of lichens in Tuchola Forest], [in:] Ochrona przyrody Borów Tucholskich. I Konferencja Naukowa, Toruń-Bydgoszcz [Nature protection of Tuchola Forest. The First Scientific Conference, ToruńBydgoszcz]. Zakład Taksonomii i Geografii Roślin, UMK Toruń, Międzywydziałowy Zakład Ochrony Środowiska ATR Bydgoszcz, Bydgoskie Towarzystwo Ekologiczne, Bydgoszcz: 154-166.

Lipnicki L. 1990. Porosty Borów Tucholskich [Lichens of the Tuchola Forests]. Acta Mycologica 26(1): 119-175.

Lipnicki L., 1991, Uwagi o potrzebie i możliwościach praktycznej ochrony porostów [Notes about the need and possibilities of practical protection of lichens], [in:] L. Lipnicki (ed.), V Zjazd Lichenologów Polskich. Porosty (Lichenes) Pszczewskiego Parku Krajobrazowego [The 5th Congress of Polish Lichenologists. Lichens of Pszczew Landscape Park]. Instytut Badań i Ekspertyz Naukowych, Gorzów Wlkp.: 103-106.

Lipnicki L., 1992, Motive und die erste Ergebnisse des praktischen Flechtenschutzes in Polen. Bryonora 9: 17-19.

Lipnicki L., 2006, Protected lichens in the Bory Tucholskie Forest (N Poland) and threats to them, [in:] A. Lackovičová, A. Guttova, E. Lisická, P. Lizoň (eds.), Central European lichens: diversity and threat. Mycotaxon Ltd., Ithaca: 331-336.

Lipnicki L., 2012, Practical protection of lichens in Poland - experience from the years 1992-2012, [in:] L. Lipnicki (ed.), Lichen Protection - Protected Lichen Species. Sonar Literacki, Gorzów Wlkp.: 43-52.

Markowski J. \& Skrok A., 1999, Zagrożenia różnorodności biologicznej, [in:] R. Olaczek, A.U. Warcholińska (eds.), Ochrona środowiska i żywych zasobów przyrody. Wyd. UŁ, Łódź: 115-127.

Matwiejuk A., 2015. Porosty objęte ochroną strefową występujące w Polsce północno-wschodniej. Studia i Materiały CEPL w Rogowie 17, 44(3): 130-137.

Motyka J., 1934, W sprawie ochrony porostów [On the protection of lichens]. Ochrona Przyrody 14: 50-56.

Öckinger E., Niklasson M. \& Nilsson S.G., 2005, Is local distribution of the epiphytic lichen Lobaria pulmonaria limited by dispersal capacity or habitat quality? Biodiversity Conservation 14: 759-773. 
Perhans K., Appelgren L., Jonsson F., Nordin U., Söderström B. \& Gustafsson L., 2009, Retention patches as potential refugia for bryophytes and lichens in managed forest landscapes. Biological Conservation 142(5): 1125-1133.

Pullin A.S., 2004, Biologiczne podstawy ochrony przyrody [Conservation Biology]. Wydawnictwo Naukowe PWN, Warszawa.

Scheidegger C. \& Werth S., 2009, Conservation strategies for lichens: insights from population biology. Fungal Biology Reviews 23(3): 55-66.

Selva S., 1994, Lichen diversity and stand continuity in the northern hardwoods and spruce-fir forests of northern New England and western New Brunswick. The Bryologist 97(4): 424-429.

Symonides E., 2007, Ochrona przyrody. Wydawnictwa Uniwersytetu Warszawskiego, Warszawa.

Szwejkowski J. \& Tobolewski Z., 1959, Zagadnienia ochrony roślin zarodnikowych [The protection of spore-plants.]. Ochrona Przyrody 26: 56-64.
Szweykowscy A. \& J. (eds.), 1993, Słownik botaniczny [Botanical Dictionary]. Wiedza Powszechna, Warszawa.

Trampler T., Kliczkowska A., Dmyterko E. \& Sierpińska A., 1990, Regionalizacja przyrodniczo-leśna na podstawach ekologiczno-fizjograficznych [Regionalization of Natural Forests according to Ecological and Physiographical Conditions]. PWRiL, Warszawa.

Umiński J., 1991, Pojezierze Krajeńskie [Krajeńskie Lakeland]. Wyd. PTTK „Kraj”, Warszawa.

Waldon B. \& Ratyńska H., 2008, Drobne zbiorniki wodne Pojezierza Krajeńskiego jako siedliska rzadkich i zagrożonych gatunków roślin [Small water bodies in the Krajeńskie Lakeland and diversity of vegetation refuges], [in:] S. Kaczmarek (ed.), Krajobraz i bioróżnorodność [Landscape and biodiversity]. Wydawnictwo Uniwersytetu Kazimierza Wielkiego, Bydgoszcz: 284-293.

Wilson O., 1999, Różnorodność życia [The Diversity of Life]. Państwowy Instytut Wydawniczy, Warszawa. 